\title{
A FUNCTIONAL-LEXEMATIC APPROACH TO THE SYNTAGMATIC AXIS OF THE SEMANTIC DIMENSION PREDICTION IN OLD ENGLISH' ${ }^{1}$
}

\author{
Marta Ma González Orta \\ Universidad de La Laguna
}

\begin{abstract}
RESUMEN: En este artículo se analiza la dimensión semántica "To say that something will happen"en inglés antiguo. Siguiendo el Modelo Lexemático-Funcional, analizaremos las estructuras sintácticas de los lexemas que componen esta dimensión, para así obtener los esquemas de predicado prototípicos de ésta y su estructuración. Para ello, en primer lugar extraeremos de A Thesaurus of Old English los verbos que indicaban predicción en inglés antiguo. El siguiente paso será localizar estos verbos en The Dictionary of Old English Corpus, el cual nos ofrecerá aquellos contextos en que estos predicados aparecían. El análisis de dichos contextos proporcionará los esquemas de predicado de esta dimensión y su estructura interna.
\end{abstract}

ABSTRACT: This paper analyses the semantic dimension "To say that something will happen" in Old English. Following the Functional-Lexematic Model, we will analyse the syntactic frames of each lexeme within this dimension in order to obtain the predicate schemata that characterise it and its structure in terms of sense-relations. Firstly, we will have access to the verbal lexemes that indicate prediction in Old English through A Thesaurus of Old English. Afterwards, The Dictionary of Old English Corpus will supply us with the contexts in which these lexemes appear, the analysis of which will provide the predicate schemata of this dimension and its internal structure

\section{Introduction: The Functional-Lexematic Model}

Following the functional-lexematic approach developed by Martín Mingorance early in the eighties, and the contributions made to the model by Mairal Usón 1993, the aim of this paper is to provide an analysis of the syntagmatic axis of the lexemes that belong to the semantic dimension "To say that something will happen" in Old English.

1. The research carried out for the writing of this paper has been supported by the Gobierno de Canarias research project PI 1999/136, "Diccionario Nuclear Sintáctico de Base Semántica del Léxico en Inglés Antiguo". This grant is hereby gratefully acknowledged. 
The functional-lexematic model is presented as a lexicographic model, since it has been "designed as a formalised 'grammatical' lexicon, organised on onomasiological principles, for the description of the core vocabulary of a language", (Martín Mingorance 1998, 103). In this way, it is intended as a development of the lexicon component of Functional Grammar: a paradigmatic model of lexical analysis has been integrated into a lexicon-based grammatical model such as Functional Grammar.

Accordingly, the structure of the lexicon consists of two axes: a syntagmatic and a paradigmatic axis. The syntagmatic axis is based on Dik's Functional Grammar, a synthetic type of grammar which provides the representation of the predicates and the hierarchical structure of the sentence; on the other hand, the paradigmatic axis is based on Coseriu's Lexematics, an analytic model which organises the core vocabulary of a language in lexical fields. The combination of these two axes highlights the fact that "lexical units are built along a paradigmatic and a syntagmatic axis, the intersection of which constitutes their meaning; the combinatorial properties of lexical units constitute as much a part of their meaning as their lexico-semantic structure", (Martín Mingorance 1998, 101-2).

These two models, Lexematics and Functional Grammar, seem to be complementary since they share a functional approach in the description of the lexical entries. Lexematics is structurally functional in considering that the system of language comes regulated by the principle of functional oppositions; Functional Grammar is teleologically functional in approaching the study of language as an instrument of social interaction.

The paradigmatic organisation of the lexicon is necessary to find evidence of the existence of certain linguistic regularities. For instance, the verbal lexemes that belong to the same semantic subdomain are usually subcategorised by the same complementation patterns. According to Faber and Mairal Usón 1998c, 37, “a verb's syntax depends on its location in semantic space. In other words, a verb's combinatory possibilities and potential syntactic patterns are semantically motivated".

Taking into account the fact that our analysis adopts a syntagmatic point of view, we will focus on the syntagmatic axis of the functional-lexematic model, expanded by Mairal Usón, with the addition of a cognitive axis. The description of the syntagmatic axis based on Functional Grammar is presented below.

\section{Description of the Syntagmatic Axis}

Certain aspects of the syntax of a predicate can be predicted taking into account the information found in the lexicon. Each predicate is represented in the lexicon in the form of a predicate frame, which contains information about its lexical form, syntactic category, number of arguments required, selection restrictions on arguments and semantic functions fulfilled by the arguments. This information provides the combinatory possibilities of each predicate, which will join with terms (expressions used 
to make reference to entities that belong to a real or imaginary world), whose inherent properties allow it. The combination of predicates and terms will result in abstract underlying structures, which after being applied syntactic and pragmatic functions will acquire the actual form of linguistic expressions by means of expression rules.

The structure of the sentence is organised hierarchically and several layers of formal and semantic organisation are distinguished: CLAUSE "speech act" (Layer 4), PROPOSITION “possible fact” (Layer 3), PREDICATION "state of affairs” (Layer 2) and PREDICATE "property/relation" (Layer 1). This is known as The Layered Hypothesis.

Thus, following Halliday 1985, Dik and Hengeveld 1990 analyse the sentence structure in two levels: the representational and the interpersonal levels. In the representational level, which is concerned with those linguistic means used by the speaker to provide the addressee with a description of a state of affairs, the PREDICATE (x) and the PREDICATION (e) would be included; whereas the interpersonal level, which is concerned with those linguistic means used by the speaker to obtain a certain communicative effect in the hearer, would include the PROPOSITION (X) and the CLAUSE (E). The following example illustrates the representation of the sentence in two levels:

Se bisceop Aidan Jam scypfarendum $p$ one storm toweardne foresægde. (Bosworth and Toller 1973: Bd. 3, 15; S. 541, 16: Ps. Th. 118, 172: 147, 8)

The bishop Aidan foretold the future storm to the sailors.

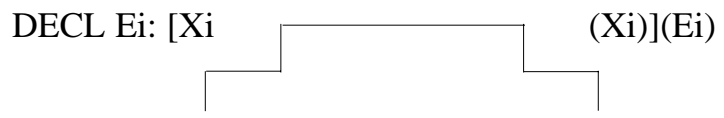

[Past ei: [foresecgan $\left(\mathrm{dlx}_{1}\right.$ : bisceop $_{\mathrm{N}}\left(\mathrm{x}_{1}\right)$ : $\left.\operatorname{Aidan}_{\mathrm{N}}\left(\mathrm{x}_{1}\right)\right) \operatorname{Ag}\left(\mathrm{dll}_{2}\right.$ : storm $_{\mathrm{N}}\left(\mathrm{x}_{2}\right)$ : toweardne $\left.{ }_{\mathrm{A}}\left(\mathrm{x}_{2}\right)\right)$ Go $\left(\mathrm{dmx}_{3}\right.$ : $\left.\left.\left.\operatorname{scypfarendum}_{\mathrm{N}}\left(\mathrm{x}_{3}\right)\right) \operatorname{Rec}\right](\mathrm{ei})\right]$

Moreover, layers one to three coincide with the different classes of entities proposed by Lyons 1977. Therefore, first-order entities correspond to physical objects that can be located in space and time; second-order entities refer to processes, events, states of affairs, which are said to take place rather than to exist; and third-order entities correspond to abstract entities which are outside space and time and can be asserted in terms of their truth. According to Austin 1962, fourth-order entities can be evaluated in terms of their felicity.

Later on, Dik and Hengeveld 1990 will integrate the hierarchical structure of the sentence in the lexical description. In so doing, they present a typology of complements depending on the type of layer underlying them and apply it to perception verbs, so that the predicates are classified according to the complements that they require. 
Turning now to the contributions on the part of Mairal Usón 1993, he suggests an enlargement of the analysis on complementation in Functional Grammar and he will consider the lexicon as the ideal place for the representation of the semantic properties of arguments.

Following Givón 1984, Mairal Usón considers verbal complementation from a semantic-cognitive approach. Givón points out the existence of a correlation between the semantic properties of verbs, the "binding" they show with their complements, and the syntactic structure of those complements. In this respect, Mairal Usón 1993, 16 proposes the Lexical Iconicity Principle: "The more coherent a given lexical category is, the more likely is the discourse level to mirror that coherence". Coherence is here understood as prototypicality.

Moreover, considering complementation as "a matter of matching the semantics of the higher predicate ... with the semantics of the complement phrase" (Mairal Usón 1993, 21), and once the semantics of the higher predicate is specified in the paradigmatic axis, he will analyse the semantic properties of complements in order to explain why certain complements are combined with some predicates and not with others.

The combinatory properties between predicates and complements are based on the combination of two scales: Scale of Evaluation or Intensional Properties and Scale of Knowledge and Behaviour or Extensional Properties. Each scale has certain semantic properties, which once combined will provide the semantic nature of complements and will also favour their appearance with certain predicates.

Extensional Properties provide the mode of presentation of complements. There are six extensions: INDIVIDUALS, ACTIONS, EVENTS, FUTURE FACTS, FACTS and SPEECH ACTS. The first three extensions possess a descriptive function, since they are concerned with the narrating event, whereas the other extensions have a content function because they are concerned with the speech event.

\begin{tabular}{||c|c|c|c|}
\hline \multicolumn{5}{|c|}{ SCALE OF KNOWLEDGE AND BEHAVIOUR } \\
\multicolumn{4}{|c|}{ EXTENSIONAL PROPERTIES } \\
\hline \hline \multirow{3}{*}{$\begin{array}{c}\text { CONTENT } \\
\text { FUNCTION }\end{array}$} & Variable & Restrictor & Extension \\
\cline { 2 - 5 } & $\mathrm{E}$ & Speech Act & Quoted Speech Act \\
\cline { 2 - 5 } & $\mathrm{X}$ & Proposition & Fact \\
\hline \multirow{3}{*}{$\begin{array}{c}\text { DESCRIPTIVE } \\
\text { FUNCTION }\end{array}$} & $\mathrm{e}$ & Predication & Future Fact \\
\cline { 2 - 5 } & & & Event \\
& $\mathrm{x}$ & Predicate & Individual / Entity \\
\hline
\end{tabular}


This scale shows that those extensions that possess a content function designate less prototypical complements, since the semantic binding between these complements and the predicates is very weak. This will give as a result a great syntactic and semantic flexibility with respect to the predicate. In the same way, verbs that are combined with these complements will present less prototypical characteristics of the verbal category (Lexical Iconicity Principle).

On the contrary, those extensions with a descriptive function designate more prototypical arguments, since they present a greater number of constraints and a greater dependency with verbs. In the same way, verbs that combine with these arguments will be more prototypical within their category: "The higher a main verb is on the binding scale, and thus the more integrated the main and complement events are cognitively-semantically, the more nominal will the morphology of the complement verb be" (Givón 1984 II, 594).

Therefore, prototypicality of complements correlates with the extent to which the predication is seen as an integrated compact event. The examples in the chart below illustrate this idea. We move from the first sentence, "I will treat you to a drink", I promise (quoted speech act complement extension), where the two propositions exist in two separate universes of discourse with the corresponding weak bond between predicate and complement, towards the last one, She prepared a delicious dish (individual complement extension), which presents a single, energised compact universe, due to the "nouny" morphology of the complemet.

\begin{tabular}{|c|c|}
\hline $\begin{array}{c}\text { COMPLEMENT EXTENSIONS } \\
\text { Quoted Speech Acts } \\
\text { e.g. "I will treat you to a drink", I promise. }\end{array}$ & SYNTACTIC/SEMANTIC RELATIONS \\
\hline Facts & weakest \\
e.g. He says that he wants to go to Bombay. & Future Facts \\
\hline e.g. I expect that she will pass the exam. \\
E.g. I saw smoke coming out of the house. \\
Actions
\end{tabular}


As far as Intensional Properties are concerned, it is argued that they determine the value of the extensions, evaluating each of them and specifying the deviations with respect to the prototypical selection restrictions established in each of the arguments. These properties appear in the form of the following scale of operators, certain, probable, possible, indeterminate, which go from the most prototypical cases to the least ones. In the case of the evaluation of a speech act, we have the following conditions: felicity, misfire, abuse, infelicity. In so being, it will be evaluated:

i) degree of appropriateness of an entity in a certain communicative context

ii) degree of occurrence of a state of affairs in a predication: if the state of affairs is the case without possible alternatives, or if it is presented as doubtful

iii) degree of the speaker's commitment to the truth contained in the proposition

iv) degree of appropriateness or felicity of a given speech act

Finally, the semantic properties of each complement (Intensional and Extensional Properties), which will indicate its selection restrictions, will be included in the predicate frame of each predicate located in the lexicon. Therefore, predicates will be classified depending on the type of complement that they require. This will provide a Four-Layered Lexicon. This theory involves an extension of the notion of predicate frame, since the argumental structure of a predicate is sensitive to the different layers within The Layered Hypothesis (Faber and Mairal Usón 1994, 214).

\section{Inclusion of a Third Axis: The Cognitive Axis}

Mairal Usón 1993 will also develop a third axis within this model: a cognitive axis. The central hypothesis stresses the idea that the semantic fields correspond to cognitive structures that fit into the concept of cognitive schema developed by Langacker 1987 and 1991. Langacker 1987, 371 defines a schema with the following words:

A schema, by contrast [to a prototype], is an abstract characterisation that is fully compatible with all the members of the category it defines (so membership is not a matter of degree): it is an integrated structure that embodies the commonality of its members, which are conceptions of greater specificity and detail that elaborate the schema in contrasting ways.

In consonance with this, Mairal Usón will conceive a cognitive schema as an element that includes the information (syntactic, semantic and pragmatic) shared by the lexemes that belong to the same semantic dimension. In this way, a cognitive schema represents the way in which a human being understands the reality and this 
conceptualisation of reality will be reflected in language. Consequently, once the selection restrictions of each complement have been established, Mairal Usón will analyse the semantic properties and the most prototypical complementation structures in each semantic dimension in order to obtain the basic cognitive schemata of the dimension.

\section{Hypothesis}

Going back to the Lexical Iconicity Principle, Faber and Mairal Usón 1994, 211 point out the general tendency of the most prototypical lexemes in a dimension to present a greater number of complementation patterns, whereas with the most specific lexemes the number of syntactic patterns decreases. This iconic principle says: "The greater the semantic coverage of a lexeme is, the greater its syntactic variation". The present paper departs form this assumption although in a reverse direction. In this way, those lexemes with a greater number of complementation patterns will show a more generic or prototypical nature within their dimension.

Until now the analysis of the paradigmatic axis had been previous to the syntagmatic one. Martín Mingorance's words reflect this view:

The fundamental postulate of this version of structural semantics, namely that the study of the paradigmatic axis of the lexicon is a necessary step which must be previous to the syntagmatic or combinatorial axis, has far-reaching methodological consequences not only for lexicological analysis but also for the lexicographic analysis of individual languages, as well as for lexicographic theory (Martín Mingorance 1998, 209).

My proposal, on the contrary, takes the analysis of the syntagmatic axis previous to the paradigmatic axis. Therefore, the first step will be the analysis of the complementation patterns of each lexeme within our dimension in order to obtain the complementation patterns of the dimension and its structure in terms of sense-relations (hyperonymy, hyponymy, synonymy, etc.).

In order to have access to the lexemes that integrate this dimension, the first step has been to obtain the verbal lexemes that indicate prediction in Old English. For this, use has been made of lexicographical products, especially A Thesaurus of Old English. Afterwards, since this research is based on The Dictionary of Old English Corpus, these lexemes will be located in their infinitival form ${ }^{2}$ in the corpus in order to obtain the contexts in which these lexemes appear.

Then the predicate and dimension schemata can be analysed. The latter will reflect the uniform behaviour of the linguistic units that conform a dimension, which can be

2. Infinitival forms have been chosen as a primary step in the compilation of the corpus. Besides, different dictionaries of Old English have been used to corroborate the data. 
seen in the following features shared by them: prototypical complementation pattern(s), qualitative valency and selection restrictions. In the case of Old English, a synthetic language, syntactic cases are also repeated. Finally, the systematic relations between arguments and their morphological features, cases and operators, will be studied.

\section{Analysis of the Semantic Dimension "To say that something will happen"}

The lexemes that integrate the dimension "TO SAY THAT SOMETHING WILL HAPPEN" are the following: bodian, foresceawian, foresecgan, foreseon, forewitegian, forhradian and getacnian.

Before analysing the internal structure of this dimension, we want to stress an interesting aspect of it, that is its location within the semantic field of speech act verbs or mental perception verbs.

Following Martín Mingorance 1998, 35, "Concerning the practical problem of establishing lexical fields, we have had to rely both on intuitive knowledge ... as well as on existing and well-established systems of organisation of lexical fields". Within these well-established systems, this author mentions Roget's Thesaurus, Longman Lexicon of Contemporary English and Casares' Diccionario Ideológico de la Lengua Española.

In these works this dimension is included under headings such as Intellect, Time and Inteligencia, respectively. Apart from the heading Time, the others would consider these verbs as cognitive verbs. In addition, I have consulted VOX Diccionario Ideológico de la Lengua Española, where this dimension is included under the heading Conocimiento, and also A Thesaurus of Old English, from where the lexemes of the dimension have been extracted and which classifies them under Mental Faculties. All these works seem to oppose to Mairal Usón 1993's classification of this dimension under speech act verbs.

As a matter of fact, indeterminacy has led me to name the dimension as "To think/say that something will happen", since these lexemes indicate some kind of "mental vision", to see in one's mind, that shows "the well known parallelism between intellection and vision" (Faber and Pérez 1993, 133), at the same time that they are speech act verbs.

That is the reason why I have considered second arguments that are predications midway between actions [+dyn][+con] and processes [+dyn][-con], which would characterise speech act verbs and mental perception verbs, respectively. Therefore, the first argument would have the semantic function Agent or Force and the second argument that of Goal. The only appropriate answer that can be given is that a syntagmatic analysis cannot account for the inclusion of a dimension in one semantic field or in another.

In relation to the internal structure of the dimension, I have to say that foreseon is supposed to be the most generic lexeme in this dimension, since it is the lexeme which presents a greater number of complementation patterns. 


\begin{tabular}{|l}
\hline SV+O \\
a) $\mathrm{S}=$ protop. hum (Ag) / (Fo) Nominative \\
b) $\mathrm{O}=\mathrm{x}$ : -animate, + /-concrete (Go) ealle mine wegas (all my ways), monige wisan (many \\
things) Accusative
\end{tabular}

On the other hand, bodian and foresecgan present a similar number and type of syntactic patterns (SVO, SV+O1+O2) and meanings ('preach', 'foresee'). Since it may be argued that there isn't enough evidence to speak of synonymy, at least it is possible to indicate that they seem to be cohyponyms. 


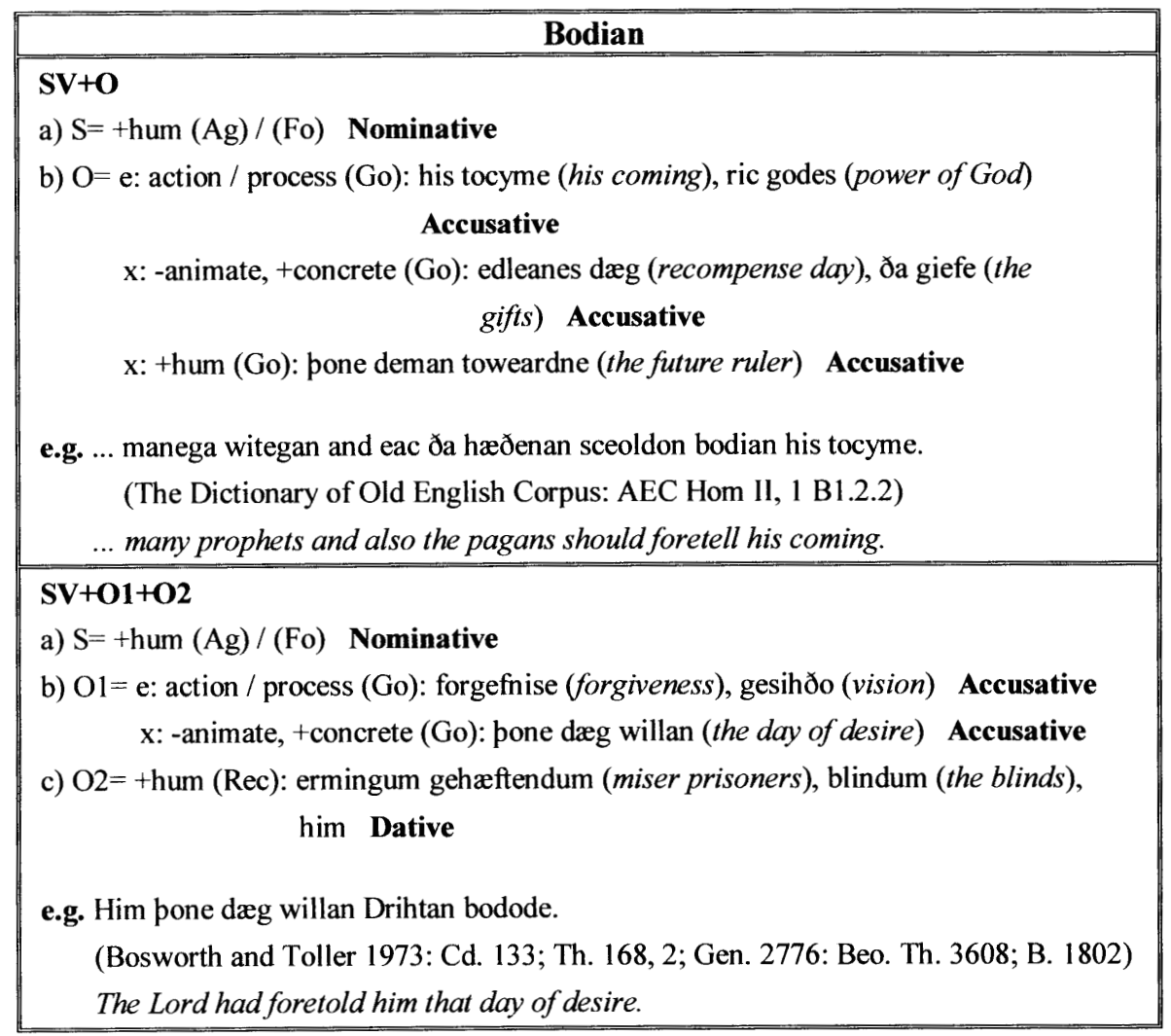

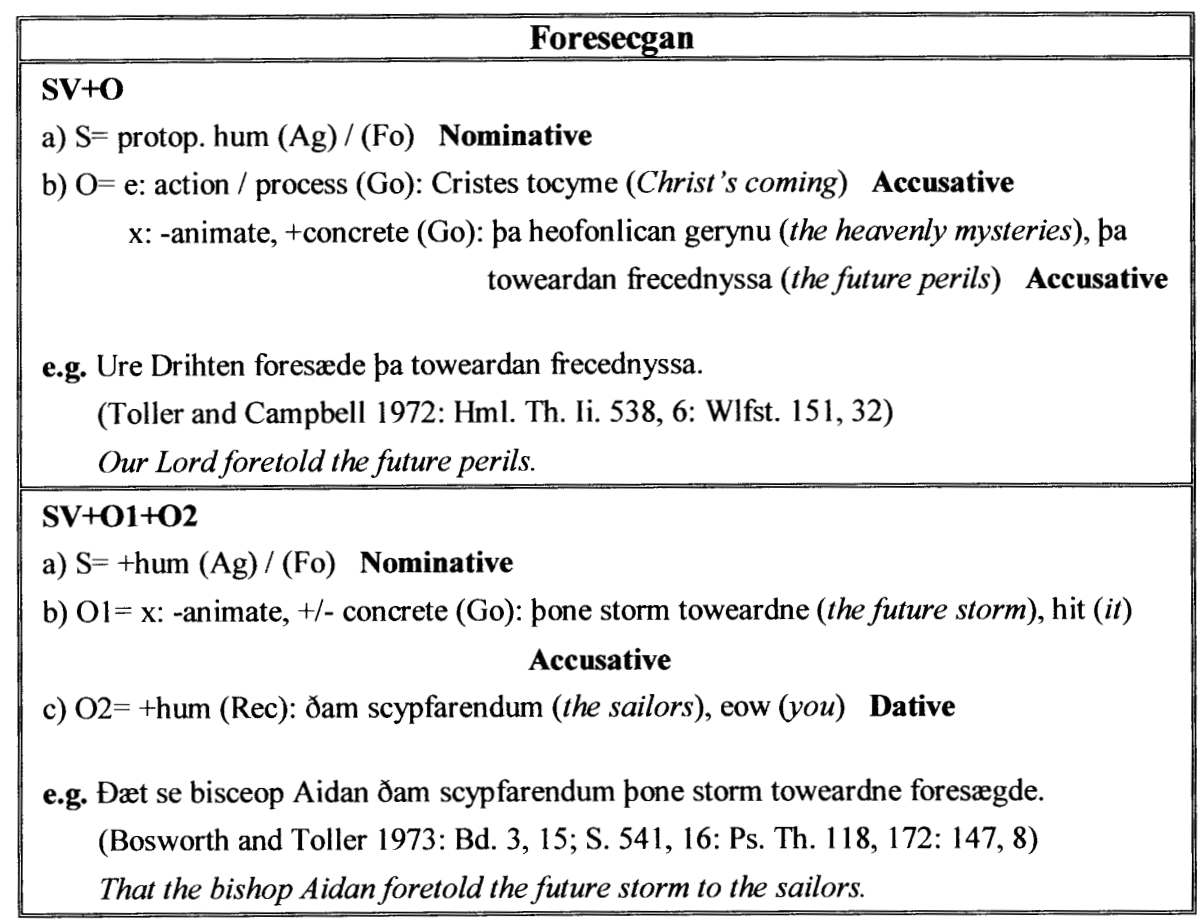


The other lexemes are analysed as follows:

\section{Foresceawian}

\section{SV+O}

a) $\mathrm{S}=$ thum $(\mathrm{Ag}) /(\mathrm{Fo})$ Nominative

b) $\mathrm{O}=\mathrm{e}$ : action / process (Go): godes mildheortnyss (God's mercy), pa genyperunge (the condemnation), hira ende (their end) Accusative $\mathrm{x}$ : -animate, +/-concrete (Go): ðone endenextan dæg (the last day), pæt fyr (the fire)

\section{Accusative}

e.g. Ic wisce ðæt hig foresceawodon hira ende. (Bosworth and Toller 1973: Deut. 32, 39)

I wish that they foresaw their end.

\section{SV+O-Wh Clause}

a) $\mathrm{S}=+$ hum $(\mathrm{Ag}) /(\mathrm{Fo})$ Nominative

b) $\mathrm{O}=\mathrm{X}$ : "Subjective Certain Future Fact" (Go)

e.g. Đæt he foresceawode hu he hig gecigde. (Bosworth and Toller 1973: Gen. 2, 19)

That he foresaw how he called her.

\section{Forewitegian}

\section{$\mathrm{SV}+\mathrm{O} 1+\mathrm{O} 2$}

a) $\mathrm{S}=$ protop. hum $(\mathrm{Ag}) /(\mathrm{Fo})$ Nominative

b) $\mathrm{Ol}=$ (contextual elision of the object)

c) $\mathrm{O} 2=$ thum $(\mathrm{Rec})$ : him Dative

e.g. ...swa swa his nama him forewitegode.

(Toller and Campbell 1972: Hml. Th. i. 50, 13)

....as if his name prophesied (it) to him.

\section{SV+O-Direct Quote}

a) $\mathrm{S}=+$ hum $(\mathrm{Ag}) /(\mathrm{Fo})$ Nominative

b) $\mathrm{O}=\mathrm{E}$ : "Direct Speech Quote" (Go)

e.g. ...\& heo ðus forewitegian ongan \& cwæð, Eala ðu eadig treow pæt alles middaneardes hælend on hangiæn sceal. (The Dictionary of Old English Corpus: LS 5 B3.3.5) ...and she thus began to prophesy and say: "Alas, you wealthy wood on which the Soviour of the world shall hang". 


\section{Forhradian}

\section{$\mathbf{S V}+\mathbf{O}$}

a) $\mathrm{S}=$ protop. hum $(\mathrm{Ag}) /(\mathrm{Fo})$ Nominative

b) $\mathrm{O}=\mathrm{e}$ : action / process (Go): godes ansyne (God's presence) Accusative $\mathrm{x}$ : -animate, $+/$-concrete $(\mathrm{Go})$ : pone timan (the time), urne endenextan dæg (our last day) Accusative

$\mathrm{x}$ : +hum (Go): us, hine (him) Accusative

e.g. Đonne hie forhradigap pone timan godes weorces.

(Bosworth and Toller 1973: Past. 39, 3)

When they anticipate the time of a good work.

\section{Getacnian}

\section{SV+O}

a) $\mathrm{S}=+$ hum $(\mathrm{Ag}) /(\mathrm{Fo})$ Nominative

b) $\mathrm{O}=\mathrm{x}$ : -animate, + concrete (Go): Godes gelaðunge (God's church) Accusative $\mathrm{x}$ : +hum (Go): urne Hælend Crist (our Saviour Christ) Accusative

e.g. Adam getacnude urne Hælend Crist. (Bosworth and Toller 1973: 6, 8)

Adam betokened our Saviour Christ.

\section{SV+O1+O-Wh Clause}

a) $S=+$ hum (Ag) / (Fo) Nominative

b) $\mathrm{Ol}=$ +hum (Rec): us Dative

c) $\mathrm{O}=\mathrm{X}$ : "Subjective Certain Future Fact" (Go)

e.g. ...pæt he geeaðmodige us to getacnian mid heofonlicum wundrum, hwelc gesetenes to fylgenne sy, hwelcum wegum to efestenne sy to ingonge his rices.

(The Dictionary of Old English Corpus: Bede 2 B9.6.4)

...that he (is) gentle to portend us with heavenly miracles, which law is to follow, which way to hurry to the access of his power.

The following chart illustrates the schemata of this dimension: 


\begin{tabular}{|c|}
\hline To think / say that something will happen \\
\hline $\begin{array}{l}\text { SV+O } \\
\text { a) } \mathrm{S}=\text { protop. hum (Ag) /(Fo) Nominative } \\
\text { b) } \mathrm{O}=\text { e: action / process (Go) Accusative } \\
\quad \mathrm{x} \text { : -animate, }+ \text {-concrete (Go) Accusative }\end{array}$ \\
\hline $\begin{array}{l}\text { SV+O1+ } 02 \\
\text { a) } \mathrm{S}=\text { protop. hum }(\mathrm{Ag}) /(\mathrm{Fo}) \text { Nominative } \\
\text { b) } \mathrm{O} 1=\text { e: action / process (Go) Accusative } \\
\quad \mathrm{x}: \text {-animate, }+/ \text {-concrete (Go) Accusative } \\
\text { c) } \mathrm{O} 2=+/ \text {-animate }(\mathrm{Rec}) \text { Dative }\end{array}$ \\
\hline
\end{tabular}

The last point to be dealt with is the relation between arguments and their morphological features. I have already indicated the cases assigned to each argument in the dimension schemata. Moreover, there is also an operator, subjunctive mood, which appears in the propositional complements of these verbs. According to Traugott 1992, 240,

The subjunctive is widely used in reported speech, as is typical in the early Germanic languages. Originally this use may have been of the 'hear-say' type in which the reporter wished to avoid commitment to the truth of what was reported, or wished to cast doubt on it. However, by Old English the use of the subjunctive had been conventionalised, ..., where there is no evidence that the reporter is casting doubt on the truth of the narrator.

See also Méndez Naya 1995, 127-44; Mitchell 1985 I, 52, 631 / II, 369-70; Quirk and Wrenn 1957, 83-84; and Traugott 1972, 98-102.

Furthermore, Mitchell 1985 II, 337 shows that one reason for the use of the subjunctive mood in complements is the reference to future time. This fact justifies the appearance of the subjunctive in the semantic dimension we are dealing with, apart from the already mentioned use of this mood in reported speech. The following examples from our semantic dimension illustrate this idea:

$p æ$ he foresceawode hu he hig gecigde. ${ }^{3}$

That he foresaw how he called her.

3. This is a case of neutralisation since this preterite form could correspond to the indicative or the subjunctive mood. However, due to its appearance in reported speech and its reference to a future time in relation to the main clause, I consider it a subjunctive form. 
Swylce eac be heora ondlifne is to pencenne \& to foreseonne, pæt heo godum peawum lifgen under ciriclecum regole ...

In such manner also by their living is to think and to foresee that they experience the good practices under the ecclesiastical rule ...

... pær he geeamodige us togetacnian mid heofonlicum wundrum, hwelc gesetenes to fylgenne sy, hwelcum wegum to efestenne sy to infonge his rices.

... that he (is) gentle to portend us with heavenly miracles, which law is to follow, which way to hurry to the access of his power.

Another aspect to be emphasised is the appearance of the auxiliary sculan in predictions. Following Traugott 1972, 68-71, there are two auxiliaries that are typical of predictions: willan and sculan. These ones used to appear in Old English depending on main clauses. In the semantic dimension we are concerned with I could find only one example with the auxiliary sculan:

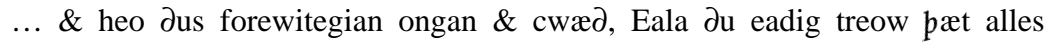
middaneardes hælend on hangiæn sceal. ${ }^{4}$

... and she thus began to prophesy and say: "Alas, you wealthy wood on which the Savior of the world shall hang."

\section{Concluding Remarks}

This paper is only the first step of a research project to elaborate a Diccionario Sintáctico del Léxico Verbal del Inglés Antiguo. This dictionary aims to be a verbal lexicon of valencies, onomasiologically organised. This type of organisation is based on the idea that our mental lexicon, which a dictionary should reflect, is organised in a hierarchical and relational way (Martín Mingorance 1998, 261).

Furthermore, I have already mentioned the fact that the meaning of a lexical unit results of the intersection between its combinatorial possibilities and its lexicosemantic structure. In that sense, a dictionary should be a combination of an onomasiological dictionary and a valency dictionary (Martín Mingorance 1998, 279).

On the other hand, at the moment there isn't any Old English dictionary that integrates the most recent advances in lexicology. Following Martín Mingorance 1998, 101,

One of the most striking and persistent paradoxes in linguistic studies is the rather ancillary status to which lexicography seems to have been tacitly

4. It is possible that the speech act in which the auxiliary sceal appears complements either the verb cwжว only or both verbs: cwad and forewitegian. However, since this auxiliary used to appear in Old English complementing those verbs that indicated prediction, we consider that this complement is shared by both verbs. On the other hand, this is the only example of a speech act complement within this dimension. 
relegated until recent times. The clearest reason for this rather incongruous state of affairs seems to be lack in adequacy of lexicographic practice in relation to the advances in linguistic theory, particularly as regards the degree of formalization attained in the other branches of linguistics, including lexical semantics.

Therefore, the aim of this dictionary is to occupy this place, since it is based on a fixed and integrating model: paradigmatic, syntagmatic and cognitive axes. Moreover, except for A Thesaurus of Old English, there isn't any Old English dictionary onomasiologically organised in lexical or conceptual fields. As a result, this dictionary will be the first syntactic dictionary of the verbal lexicon in Old English, hopefully a helpful tool for the research in the history of the English language.

\section{References}

Austin, J.L. 1962. How to do things with words. Cambridge, Massachusetts: Harvard U. P.

Bosworth, J. and T.N. Toller. 1 ${ }^{\text {st }}$ Edition. 1898. Reprinted 1973. An Anglo-Saxon Dictionary. Oxford: Oxford University Press.

CASARES, J. 1990. Diccionario Ideológico de la Lengua Española. Barcelona: Ed. Gustavo Gili.

Coseriu, E. 1981. Principios de Semántica Estructural. Madrid: Gredos.

DIK, S.C. 1997a. The Theory of Functional Grammar - Part I: The Structure of the Clause. Ed. Kees Hengeveld. Berlin/New York: Mouton de Gruyter.

DIK, S.C. 1997b. The Theory of Functional Grammar - Part 2: Complex and Derived Constructions. Ed. Kees Hengeveld. Berlin/New York: Mouton de Gruyter.

DIK, S.C. and K. HENGEVELD. 1990. "The hierarchical structure of the clause and the typology of perception verb complements". Working Papers in Functional Grammar, 37. Amsterdam: University of Amsterdam.

FABER, P. and R. MAIRAL USÓN. 1994. "Methodological underpinnings for the construction of a functional lexicological model". Miscelanea: A Journal of English and American Studies, 15. 193-217.

FABER, P. and R. MAIRAL Usón. 1998c. “Towards a Semantic Syntax". Revista Canaria de Estudios Ingleses, 36. University of La Laguna: Servicio de Publicaciones. 37-64.

FABER, P. and C. PÉREZ. 1993. "Image schemata and light: A study of contrastive lexical domains in English and Spanish". Atlantis, 15. 117-34.

Givón, T. 1984. Syntax. A Functional Typological Introduction. Vol. I / II. Amsterdam/Philadelphia: John Benjamins.

HALlIDAY, M.A.K. 1985. An Introduction to Functional Grammar. London: Arnold.

HeAley, A. di P. Ed. The Dictionary of Old English Corpus. Web site ISBN 0-47200277-5. 
LANGACKER, R.W. 1987. Foundations of Cognitive Grammar. Vol. I. Stanford: Stanford U. P.

LANGACKER, R.W. 1991a. Foundations of Cognitive Grammar. Vol. II. Stanford: Stanford U.P.

LYONS, J. 1977. Semantics. Vol. I / II. Cambridge: C.U.P.

MAIRAL Usón, R. 1993. Complementation Patterns of Cognitive, Physical Perception and Speech Act Verbs in the English Language. A Functional-Cognitive Approach. Unpublished PhD Thesis. University of Zaragoza.

Martín Mingorance, L. 1998. El Modelo Lexemático-Funcional. El Legado Lingüístico de Leocadio Martín Mingorance. Ed. A. Marín Rubiales. Granada.

MCARTHUR, T. 1981. Longman Lexicon of Contemporary English. London: Longman.

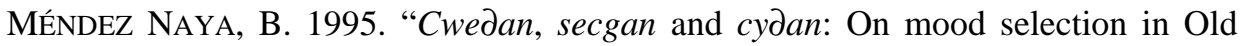
English dependent statements". Atlantis, 17. 127-44.

MitCHELL, B. 1985. Old English Syntax. Vol. I / II. Oxford: O.U.P.

QUIRK, R. and C.L. WrEnN. 1957. An Old English Grammar. London: Methuen.

RoBERTS, J. and C. KAY. 1995. A Thesaurus of Old English. London: King's College London Medieval Studies.

Roget's Thesaurus of English Words and Phrases. 1975. London: Longman.

Toller, T.N. and A. CAMPBEll. ${ }^{\text {st }}$ Edition 1921. Reprinted 1972. An Anglo-Saxon Dictionary. Supplement. Oxford: Oxford University Press.

TRAugOTT, E.C. 1972. A History of English Syntax. New York: Holt.

TraugotT, E.C. 1992. "Syntax". The Cambridge History of the English Language. Vol. I. Ed. R.M. Hogg. Cambridge: C.U.P. 168-286.

VOX Diccionario Idelógico de la Lengua Española. 1995. Barcelona: Biblograf. 